\title{
Mass and energy integration study of hydrothermal carbonization with anaerobic digestion of sewage sludge
}

\author{
C.I. Aragón-Briceño ${ }^{\text {a, d, * }}$, A.B. Ross ${ }^{\text {b }}$, M.A. Camargo-Valero ${ }^{\text {a, c }}$ \\ ${ }^{a}$ BioResource Systems Research Group, School of Civil Engineering, University of Leeds, LS2 9JT, Leeds, United Kingdom \\ ${ }^{\mathrm{b}}$ School of Chemical and Process Engineering, University of Leeds, LS2 9JT, Leeds, United Kingdom \\ ${ }^{\mathrm{c}}$ Departamento de Ingeniería Química, Universidad Nacional de Colombia, Campus La Nubia, Manizales, Colombia \\ ${ }^{\mathrm{d}}$ Department of Thermal and Fluid Engineering, University of Twente, Drienerlolaan 5, 7522 NB, Enschede, the Netherlands
}

\section{A R T I C L E I N F O}

\section{Article history:}

Received 15 June 2020

Received in revised form

12 November 2020

Accepted 18 November 2020

Available online 23 November 2020

\section{Keywords:}

Hydrothermal carbonization

Anaerobic digestion

Process waters

Sewage sludge

\begin{abstract}
A B S T R A C T
Anaerobic Digestion is the most common process used for energy generation from sewage sludge but only one half of the sewage sludge is susceptible to biodegradation. Hydrothermal Carbonization is considered an option for harness all the energy embedded in sewage sludge because of its high-value products (Hydrochar and Process waters). The integration AD followed by HTC is a recent approach that is still under development. The challenge is to provide evidence for coupling HTC with the existing infrastructure at wastewater treatment works. In this work, a mass and energy integration study of the potential of coupling HTC with AD for sewage sludge treatment was evaluated. Six proposed process configurations were built using primary sludge, secondary sludge and a mix, in order to evaluate net waste generation, fate of nutrients, net energy production and potential economic benefits. The proposed scenarios showed an overall total solid and COD reduction up to 68 and 66\% respectively. The inclusion of hydrochar as a fuel source increased the net energy production 10 times compared when only biogas is considered as an energy source. The potential struvite production ranged from 0.02 to $0.06 \mathrm{~kg}$ per tonne of sludge treated. Scenarios with $250{ }^{\circ} \mathrm{C}$ thermal treatment temperature provided better economic benefits when struvite and hydrochar are considered.
\end{abstract}

(C) 2020 Elsevier Ltd. All rights reserved.

\section{Introduction}

The use of sewage sludge as a feedstock for renewable energy generation is gaining growing attention. In the UK, the estimated annual production of sewage sludge is 1.4 million tonnes (dry weight) [1] in which the water industry generates approximately $800 \mathrm{GW} \mathrm{h} / \mathrm{yr}$ of electrical energy [2]. The sewage sludge produced at waste water treatment works (WWTW) has been commonly treated by anaerobic digestion (AD) due its large organic matter content which favours biogas production and brings multiple environmental benefits [3-5]. According to Berglund and Börjesson [5], 40-80\% of the energy content of the biogas produced from sewage sludge in a WWTW corresponds to the overall energy input in a large-scale biogas plant. Furthermore the inclusion of AD

\footnotetext{
* Corresponding author. Department of Thermal and Fluid Engineering, University of Twente, Drienerlolaan 5, 7522 NB Enschede, the Netherlands.

E-mail addresses: c.i.aragonbriceno@utwente.nl (C.I. Aragón-Briceño),A.B.Ross@ leeds.ac.uk (A.B. Ross), M.A.Camargo-Valero@leeds.ac.uk (M.A. Camargo-Valero).
}

brings associate benefits as sludge mass reduction, odour removal and pathogen reduction [6]. Nevertheless, one of the main limiting steps of processing sewage sludge via $A D$ is the solubilisation of biodegradable organic compounds through hydrolysis [7,8]. For that reason, the resulting digested sludge (digestate) from anaerobic digestion still contains large amounts of non-easy biodegradable organic matter that with a proper treatment can be harnessed for additional energy production [3]. Many pre-treatment techniques based on thermal, biological, chemical, mechanical and physical processes have been studied individually and in combination with the objective to enhance the biodegradability sewage sludge and digestate by breaking down complex organic molecules in order to increase the solubility of organic compounds and produce more energy coming from biogas [6]. However, the main drawback has been the economic constraints for scale-up and commercialisation [6].

Hydrothermal processing is currently being considered as a novel alternative technology to further harness energy from sewage sludge and digestate [9-11] and to reduce the issues related to current disposal of final solid products. Hydrothermal processes 
(HTPs) involve the treatment of biomass in hot compressed water that can produce either solid hydrochar, a biocrude or a syngas, along with process waters, depending on process temperature and pressure. In addition, HTPs applied to sewage sludge processing not only help to inactivate pathogens and further bacterial activity after disposal, but also produce valuable by-products like hydrochar.

In recent years, some researchers have proposed HTC as an alternative to harness better the properties from the sewage sludge and reducing waste generation [3,9-18]. HTC main objective is to transform biomass into a carbon-rich product applying heat $\left(180-250^{\circ} \mathrm{C}\right)$ and pressure during a certain period of time [9,18-21]. The main advantage of HTC is that it is carried out in presence of water avoiding the energy-intensive drying step required for thermal processes [3,9,21,22]. Furthermore, the resulting products from the HTC are a solid hydrochar that can be used as a soil amender or fuel source and a process water rich in carbon and organics that can be used for enhanced biogas production [3,12-15,20,23-29].

There are several studies of HTC applied to sewage sludge at labscale focused in the process-conditions and their influence on the by-products [3,12,18,23-25,27,30-36]. Nevertheless, only few studies have focused in the potential technical performance of industrial-scale of the HTC plants [9,12,19,37-39]. Companies as SunCoal Industries, AVA-CO2 and Ingelia [40-44] have developed commercial applications for HTC, but this technology is still under development. CarboRem and Terranova Energy have developed modular HTC units that makes easier the HTC integration within a waste water system $[42,44]$. According to the study carried out by Child [45] and Lucian and Fiori [19], a HTC plant can cost from $€ 1.7$ up to $€ 10$ million depending on treatment capacity ( 8000 to 50,000 tonnes of feedstock). Nevertheless, both studies focused on hydrochar production using mostly lignocellulocic biomass as main feedstock.

Other studies have found that the biogas production at AD plants using thermal hydrolysis as pre-treatment is better than using hydrothermal treatments as post-treatment, but the use of hydrochars despite of being considered a low-grade fuel gives an added value boosting up the energy production up to $179 \%$ compared with the $43 \%$ of the thermal hydrolysis [3]. This makes the integration of hydrothermal treatment as post-treatment a promising option to harness the energy from sewage digestate [3]. Nonetheless, those studies just mention the energetic benefits of integrating hydrothermal processes with $\mathrm{AD}$, but did not consider other implications as energy consumption, potential economic benefits and mass and energy balances $[3,12]$.

The integration of HTC as a post-step after the AD is a recent approach and some authors suggest that the integration of a hydrothermal treatment step into waste water systems are energy positive [3,9,12,14,15,17,23-25,27,46-49]. The use of hydrochars as a source of energy, despite being considered a low-grade fuel, can boost up the energy production up to $179 \%$ compared with the $43 \%$ of the thermal hydrolysis used as a pre-treatment [3]. This makes the integration of hydrothermal treatment as post-treatment a promising option to harness the energy from sewage digestate. Medina-Martos et al. [9], made a techno-economic and life cycle assessment of an integrated HTC system for sewage sludge. They found that the integration of the HTC system helps to reduce environmental impact compared with the conventional WWT configutarion with AD integrated. The energy efficiency can increase up to $14 \%$ but the costs of integrating the HTC + AD system increases up to $42 \%$ compared with the conventional WWT with AD.

Considering this novel approach of integrating $\mathrm{HTC}+\mathrm{AD}$, the current state of the art and in order to meet sustainable environmental targets in sewage sludge management such as waste minimisation, resource recovery and the overall reduction of treatment costs, it is imperative to provide evidence from integration studies coupling HTC with the existing infrastructure and treatment units at WWTWs. Therefore, the main objective of this study is to assess the integration of HTC with AD through robust mass and energy balances from several proposed process configurations using different sewage sludge streams and supported by results obtained from experimental work. Results were used to evaluate and compare products yields, waste generation, net energy implications and potential economic benefits, in order to integrate HTC as part of a comprehensive sewage sludge management strategy.

\section{Material and methods}

\subsection{Process description}

The overall proposed process of hydrothermal carbonization integration to anaerobic digestion of sewage sludge is divided in four main processing areas (See Fig. 1). Firstly, the feed undergoes mesophilic anaerobic digestion processing $\left(37^{\circ} \mathrm{C}\right)$ producing digestate and biogas. The next process comprises a thickener which concentrate the digestate to $15 \%$ of solids. Next, the thickened digestate is submitted to thermal processing ( 160 or $250{ }^{\circ} \mathrm{C}$ ) converting it into process water and hydrochar - i.e., for the energy balance, the thermal recovery efficiency from the heat exchanger is considered in this stage. The treatment temperatures were selected based on previous studies to emulate and compare the conditions of hydrothermal hydrolysis $\left(160{ }^{\circ} \mathrm{C}\right)$ and HTC of sewage sludge in different scenarios $[3,12]$. Then, a centrifuge is used to separate the hydrochar (solid fraction) from the process water (liquid fraction). The hydrochar is considered as a potential fuel source based on their higher heating values (HHV), but non-energy recovery process is considered at this step. On the other hand, the process water is anaerobically treated at mesophilic conditions in a second reactor producing biogas. The biogas produced at the first and second $\mathrm{AD}$ reactors are mixed combusted in a combine heat power (CHP) unit to produce the energy for the system. The energy produced from the biogas is used to cover the energy requirements of the hydrothermal system and the exceeding energy is used for other equipment.

The aim of the process configuration is to integrate the hydrothermal treatment as a post-treatment to the anaerobic digestion of sewage sludge. The use of different sewage digestate is to compare the energy production between them since the primary sludge seems to have high organic content. As stated by Pérez-Elvira and Fdz-Polanco [50], it is expected that the best option would be to segregate primary and secondary sludge in order to produce more energy in the overall system and that is the overall hypothesis of the work conducted.

The assumptions adopted as a basis for the mass and energy balance of the different scenarios built in this study are presented in Table 1.

\subsection{Mass and energy balances}

This study is based on the experimental results obtained from laboratory experiments carried out at University of Leeds (UK). Six scenarios were tested using three different sewage sludges (Primary, Secondary and Primary-Secondary Mix) following the proposed process description and undertaking hydrothermal processing at two different temperatures (160 and $250{ }^{\circ} \mathrm{C}$ ).

\subsubsection{Sludge samples}

Sludge samples of primary sludge (PS) and secondary sludge (SS) were collected at Yorkshire Water's Esholt WWTW in Bradford, UK. All sludge samples were stored at $4{ }^{\circ} \mathrm{C}$ after collection and then 


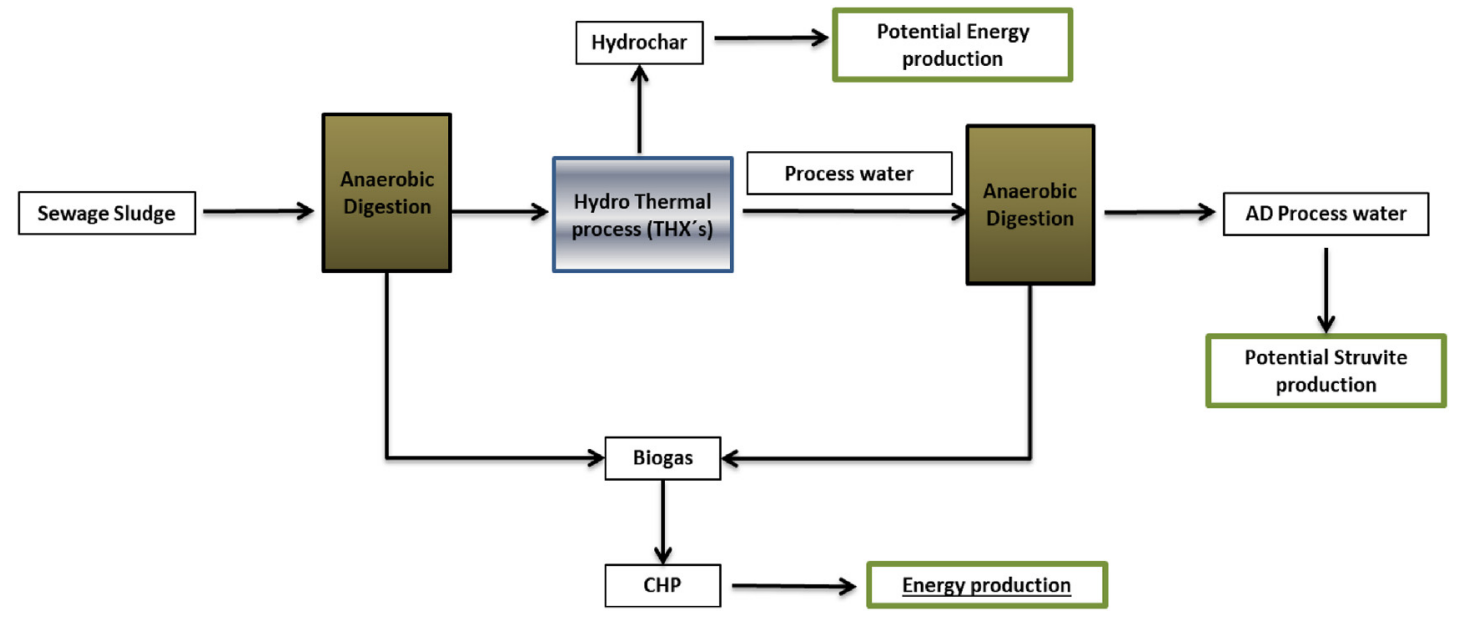

Fig. 1. General process diagram for the proposed scenarios.

Table 1

Process assumptions and calculation basis considered for the mass and energy balances of the different scenarios.

\begin{tabular}{|c|c|c|c|c|c|c|c|}
\hline Description & Sc1 & Sc2 & Sc3 & Sc4 & Sc5 & Sc6 & References \\
\hline Sludge to be treated $(\mathrm{kg})$ & 1000 & 1000 & 1000 & 1000 & 1000 & 1000 & Assumed \\
\hline Feeding sludge & PS & SS & Mix & PS & SS & Mix & Considered \\
\hline Solids concentration (\%DS) & 15 & 15 & 15 & 15 & 15 & 15 & Assumed \\
\hline Anaerobic Digestion temperature $\left({ }^{\circ} \mathrm{C}\right)$ & 37 & 37 & 37 & 37 & 37 & 37 & Considered \\
\hline Anaerobic Digestion retention time (Day) & 21 & 21 & 21 & 21 & 21 & 21 & Considered \\
\hline Thermal treatment temperature $\left({ }^{\circ} \mathrm{C}\right)$ & 160 & 160 & 160 & 250 & 250 & 250 & Considered \\
\hline Thermal treatment retention time $(\mathrm{H})$ & 0.5 & 0.5 & 0.5 & 0.5 & 0.5 & 0.5 & Considered \\
\hline Recovery of heat energy from thermal treatment (\%) & 85 & 85 & 85 & 85 & 85 & 85 & $\begin{array}{l}\text { Shemfe, Gu and Ranganathan [53] and Sridhar Pilli, Song Yan, R. D. Tyagi and R. } \\
\text { Y. Surampalli [54] }\end{array}$ \\
\hline Raw sludge COD removal during $\mathrm{AD}(\%)$ & 38 & 48 & 44 & 38 & 48 & 44 & Experimental Values \\
\hline Process Water COD removal during AD (\%) & 47 & 42 & 37 & 59 & 59 & 60 & Experimental Values \\
\hline $\begin{array}{l}\text { Methane production of raw sludge }\left(\mathrm{m}^{3} \text { of methane/ }\right. \\
\text { Ton of COD) }\end{array}$ & 129 & 116 & 226 & 129 & 116 & 226 & Experimental Values \\
\hline $\begin{array}{l}\text { Methane production of Process Water }\left(\mathrm{m}^{3} \text { of }\right. \\
\text { methane/Ton of COD) }\end{array}$ & 130 & 207 & 204 & 218 & 212 & 232 & Experimental Values \\
\hline $\begin{array}{l}\text { Energy required for thermal treatment (MJ*kg-1 of } \\
\text { dry feedstock) }\end{array}$ & 3.3 & 3.3 & 3.3 & 5.9 & 5.9 & 5.9 & Experimental Values \\
\hline Hydrochar yield (\%) & 50 & 55 & 56 & 37 & 40 & 40 & Experimental Values \\
\hline Solids separator Energy consumption (kW/Dry tonne) & 108 & 108 & 108 & 108 & 108 & 108 & Smith and Liu [55] \\
\hline - Centrifuge & & & & & & & \\
\hline Energy required for Mixing in the $\mathrm{AD}$ (kW/Dry tonne) & 7 & 7 & 7 & 7 & 7 & 7 & $\begin{array}{l}\text { Oreggioni, Gowreesunker, Tassou, Bianchi, Reilly, Kirby, Toop and Theodorou } \\
\text { [56] }\end{array}$ \\
\hline
\end{tabular}

used for the hydrothermal treatments prior characterisation. The analytical methods for the characterisation of the raw biomass followed the methodology described in Aragón-Briceño, Grasham, Ross, Dupont and Camargo-Valero [12].

\subsubsection{Anaerobic treatments}

Primary (PS), secondary (SS) and 1:1 mix of primary-secondary (MIX) sludge were processed by anaerobic treatment for 30 days in the lab, before further hydrothermal processing. Resulting samples were named as follows: digested primary sludge - ADPS; digested secondary sludge - ADSS; and digested mix of PS and SS - ADMIX.

$\mathrm{AD}$ tests were carried out following the method described by Aragón-Briceño, Ross and Camargo-Valero [3,12] using sewage sludge samples and process waters separated from HTC experiments. The inoculum concentration used in each batch for the BMP tests was $1: 1 \mathrm{vol}$ inoculum to substrate ratio ( $\cong 10 \mathrm{~g} / \mathrm{L}$ VS of inoculum and $\cong 2 \mathrm{~g} / \mathrm{L}$ of COD of process waters). The batch experiments were performed in multiple series of $120-\mathrm{mL}$ bottles sealed with a rubber stopper and aluminium cap at $37^{\circ} \mathrm{C}$ for 21 days. All the $\mathrm{AD}$ tests were conducted in duplicate. Distilled water was used for diluting samples to help them to reach the set COD concentration and volume ( $60 \mathrm{~mL}$ for each reactor). Each bottle was purged with nitrogen to keep anaerobic conditions and avoid the presence of oxygen inside the bottle. Test bottles were kept undisturbed at all time, apart when mixing by hand during biogas production measurements. Methane production was monitored by using a volumetric method with a solution of $1 \mathrm{M} \mathrm{NaOH}$. Volumetric methane production is corrected for temperature and pressure and reported at standard conditions $\left(0{ }^{\circ} \mathrm{C}\right.$ and $\left.1 \mathrm{~atm}\right)$. For every measurement, a bottle was taken out and sacrificed for conducting lab analyses. All the analyses were carried out in duplicate.

\subsubsection{Hydrothermal experiments}

Thermal experiments were conducted in a non-stirred $500 \mathrm{~mL}$ stainless steel batch Parr reactor. In each batch experiment $220 \mathrm{~mL}$ of sludge sample $(2.5 \% \mathrm{w} / \mathrm{w})$ were loaded in the reactor and sealed. Hydrothermal treatments were performed at $160{ }^{\circ} \mathrm{C}$ for $30 \mathrm{~min}$ at 5 bar and at $250{ }^{\circ} \mathrm{C}$ for $30 \mathrm{~min}$ at 40 bar with heating rates of $\cong 5.3$ and $4.2^{\circ} \mathrm{C} / \mathrm{min}$ respectively. After treatment, the reactor was cooled down to $25^{\circ} \mathrm{C}$. The hydrochars and process waters were processed 
and analysed according to the methodology described by AragónBriceño, Ross and Camargo-Valero [3,12]. Solids samples (Hydrochar and sewage solid fraction) were dried for 7 days at $40{ }^{\circ} \mathrm{C}$ in an oven and weighted afterwards.

\subsubsection{Solid and liquid samples characterisation}

The solid and liquid characterisation was used to calculate the mass and energy balances of the different scenarios. Raw sludge and different hydrochar were analysed in a CHNS analyser (Elemental Analyser, CE Instruments Flash EA 1112 Series) to perform ultimate analyses of dry hydrochars (See Table 2).

The process waters (PW) were processed following standard methods for the characterisation of wastewater samples, for Chemical Oxygen Demand (COD), Total Solids (TS), Total Suspended Solids (TSS), Total Phosphorus, Total Kjeldahl Nitrogen (TKN) and Biomethane Potential (BMP) (See results in Figs. 2 and 3).

\subsubsection{Hydrochar yield}

Hydrochar yield $(Y)$ was determined as reported by AragónBriceño, Ross and Camargo-Valero [3,12]:

$Y(\%)=\frac{\text { mass of dry hydrochar }}{\text { mass of dry Substrate feedstock }} * 100$

\subsubsection{High heating value (HHV)}

In order to know the theoretical calorific value of the hydrochar, the Dulong equation reported by Channiwala and Parikh [51] was used.

$$
\begin{aligned}
\text { HHV }\left(\mathrm{MJxKg}{ }^{-1}\right) & =0.336(\text { \%Carbon })+1.433(\% \text { Hydrogen } \\
& \left.-\left(\frac{\% \text { Oxygen }}{8}\right)\right)+0.0942(\% \text { Sulphur })
\end{aligned}
$$

\section{Table 2}

Results from the CHNS analysis of the different sewage sludge and hydrochar in dry

\begin{tabular}{|c|c|c|c|c|c|}
\hline \multirow[t]{2}{*}{ Sample } & \multicolumn{5}{|c|}{ Ultimate analysis } \\
\hline & $\mathrm{C}(\%)$ & $\mathrm{H}(\%)$ & $\mathrm{N}(\%)$ & $\mathrm{O}^{\mathrm{a}}(\%)$ & $\mathrm{S}(\%)$ \\
\hline Primary Sludge & 40.3 & 6.6 & 3.3 & 23.7 & 0.4 \\
\hline Secondary Sludge & 33.5 & 5.5 & 4.1 & 28.5 & 0.2 \\
\hline Mix Sludge & 35.5 & 5.8 & 3.3 & 28.0 & 0.1 \\
\hline AD Primary Sludge & 31.1 & 5.1 & 3.0 & 24.0 & 0.5 \\
\hline AD Secondary Sludge & 32.2 & 5.2 & 3.4 & 23.5 & 0.6 \\
\hline AD Mix Sludge & 30.9 & 5.0 & 3.0 & 24.1 & 0.7 \\
\hline \multicolumn{6}{|c|}{ Hydrochars from $160{ }^{\circ} \mathrm{C}$ to $30 \mathrm{~min}-5 \mathrm{Bar}$} \\
\hline Primary Sludge & 40.3 & 6.3 & 2.1 & 22.5 & 0.1 \\
\hline Secondary Sludge & 33.1 & 5.3 & 3.3 & 21.7 & 0.7 \\
\hline Mix Sludge & 37.5 & 6.0 & 2.6 & 21.6 & 0.5 \\
\hline AD Primary Sludge & 28.9 & 4.5 & 2.1 & 19.8 & 0.5 \\
\hline AD Secondary Sludge & 29.4 & 4.6 & 2.4 & 19.1 & 0.6 \\
\hline AD Mix Sludge & 29.9 & 4.6 & 2.5 & 18.9 & 0.6 \\
\hline \multicolumn{6}{|c|}{ Hydrochars from $250^{\circ} \mathrm{C}$ to $30 \mathrm{~min}-40 \mathrm{Bar}$} \\
\hline Primary Sludge & 37.4 & 5.3 & 1.0 & 15.6 & 0.1 \\
\hline Secondary Sludge & 36.1 & 4.6 & 1.9 & 11.6 & 0.5 \\
\hline Mix Sludge & 35.8 & 5.2 & 1.1 & 15.2 & 0.3 \\
\hline AD Primary Sludge & 27.3 & 3.8 & 1.1 & 11.4 & 0.3 \\
\hline AD Secondary Sludge & 27.5 & 3.8 & 1.3 & 11.6 & 0.4 \\
\hline AD Mix Sludge & 26.6 & 3.7 & 1.1 & 12.6 & 0.3 \\
\hline
\end{tabular}
basis.

${ }^{\text {a }}$ Calculated as difference between sum of $\mathrm{C}, \mathrm{H}, \mathrm{N}, \mathrm{S}$, ash.

\subsubsection{Biochemical Methane Potential (BMP)}

In order to assess the performance of methane production by gram of chemical oxygen demand (COD) added, the following BMP formula was used:

$B M P=\frac{V_{\mathrm{CH}_{4}}-V_{\mathrm{CH}_{4}, \text { blank }}}{(\text { Mass of } \mathrm{COD} \text { fed in biodigester })}$

where:

$\mathrm{BMP}=$ Biochemical Methane Potential $\left(\mathrm{ml}\right.$ of $\mathrm{CH}_{4} / \mathrm{g}$ of $\mathrm{COD}$ added)

$\mathrm{V}_{\mathrm{CH} 4}=$ Volume of methane produced in bottle $(\mathrm{mL})$

$\mathrm{V}_{\mathrm{CH} 4 \text {, blank }}=$ Volume of methane produced in the blanks $(\mathrm{mL})$

Mass of COD $=$ Mass of COD of the substrate ( $\mathrm{g}$ of COD substrate)

\subsubsection{Thermal treatment energy calculations}

The energy required for the thermal treatments was based on the energy required calculations to heat water in a closed batch system as stated by Berge, Ro, Mao, Flora, Chappell and Bae [16]. Assuming that the heater has $100 \%$ resistance, there is no heating losses in the tank during the thermal treatment and the volume of the water remain constant, the energy required was determined by the followed equations:

$M_{\text {water total }}=\rho_{\text {sat.-liq }} * V_{\text {sat.-liq }}+\rho_{\text {sat.gas }} * V_{\text {sat. } \text { gas }}$

$V_{\text {reactor }}=V_{\text {sat.-liq }}+V_{\text {sat.-gas }}$

$H_{T}=\left[\rho_{\text {sat.-liq }} * V_{\text {sat.-liq }} * H_{\text {sat. }- \text { Liq }}+\rho_{\text {sat.gas }} * V_{\text {sat.-gas }} * H_{\text {sat. }- \text { gas }}\right]$

where:

$\mathrm{M}_{\text {water total }}$ is the mass of the water input into the reactor [g]. $\rho_{\text {(sat.-liq) }}$ is the density of the saturated water at the thermal treatment temperature $[\mathrm{g} / \mathrm{L}]$.

$\rho$ (sat.-gas) is the density of the saturated water vapour at the thermal treatment temperature $[\mathrm{g} / \mathrm{L}]$.

$\mathrm{V}_{\text {sat.-liq }}$ is the Volume of the water in liquid fraction [L].

$\mathrm{V}_{\text {sat.-gas }}$ is the Volume of the water in gas fraction [L].

$\mathrm{V}_{\text {reactor }}$ is the volume of the reactor [L].

$\mathrm{H}_{\text {sat.liq }}$ is the enthalpy of the saturated water at the thermal treatment temperature $[\mathrm{J} / \mathrm{g}]$.

$\mathrm{H}_{\text {sat.-gas }}$ is the enthalpy of the saturated water vapour at the thermal treatment temperature $[\mathrm{J} / \mathrm{g}]$.

$\mathrm{H}_{\mathrm{T}}$ is the energy required to heat up the water [J],

However in order to obtain the results in $\mathrm{kWh}$, the following relation was taken into account: $1 \mathrm{~J}=2.777 \times 10^{-7} \mathrm{~kW} \mathrm{~h}$.

\section{Results and discussions}

\subsection{Mass balance}

The experimental data obtained from lab experiments and overall considerations made (see Table 2) were used for assessing mass and energy balances of the different thermal treatments integrated to anaerobic digestion and to assess the scenarios shown in Figs. 2 and 3. Six scenarios were built, compared and assessed, considering three different sewage sludge streams (PS, SS and Mix) at two different thermal treatment temperatures ( 160 and $250{ }^{\circ} \mathrm{C}$ ). In this study $1,000 \mathrm{Kg}$ as initial mass of sewage sludge was considered with $15 \% \mathrm{w} / \mathrm{w}$ of initial solid concentration. The initial 
a) Scenario 1

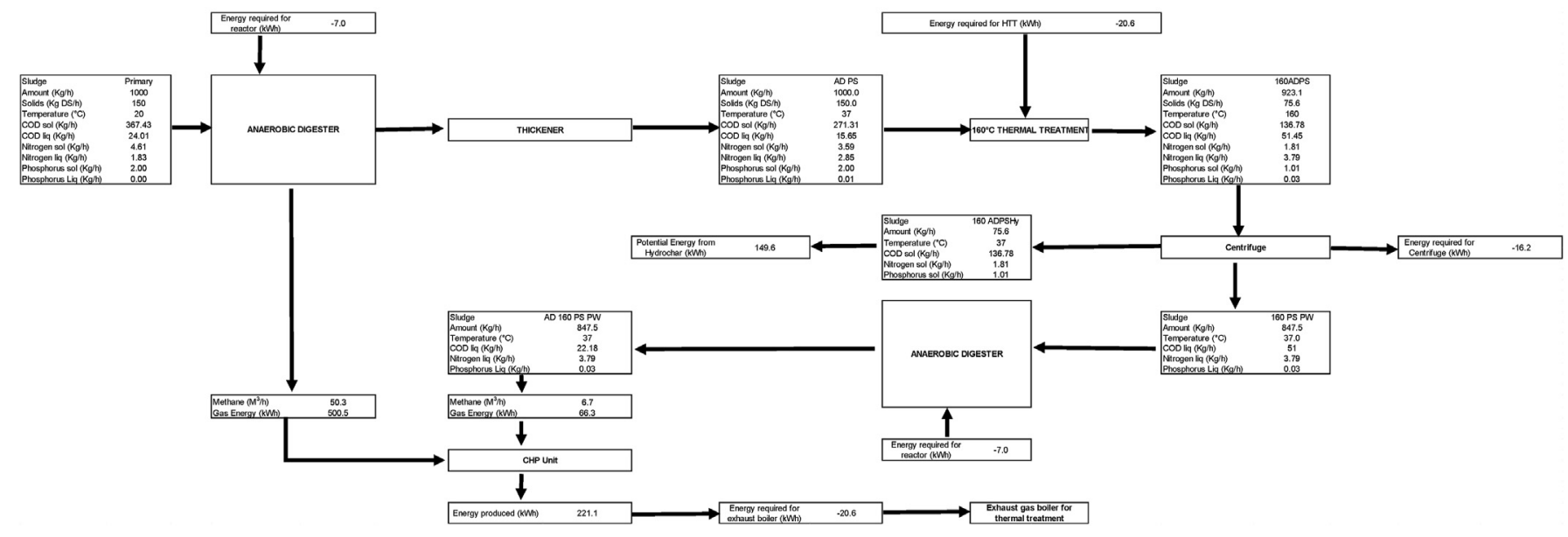

b) Scenario 2

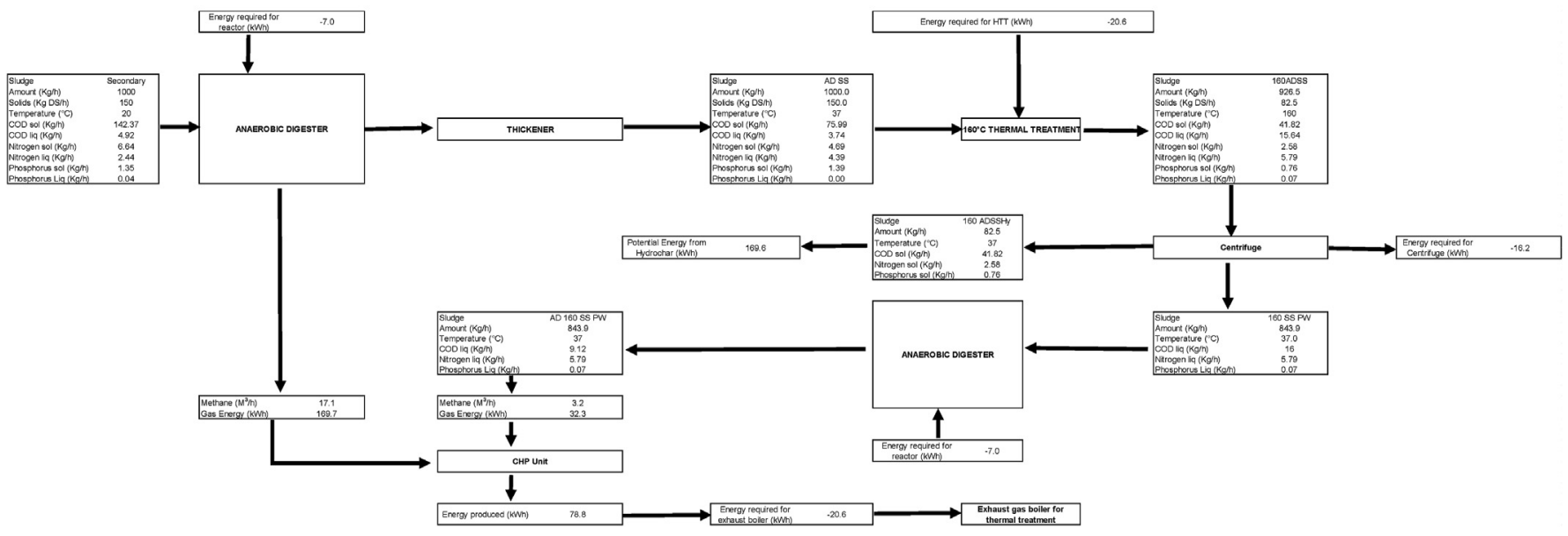

c) Scenario 3

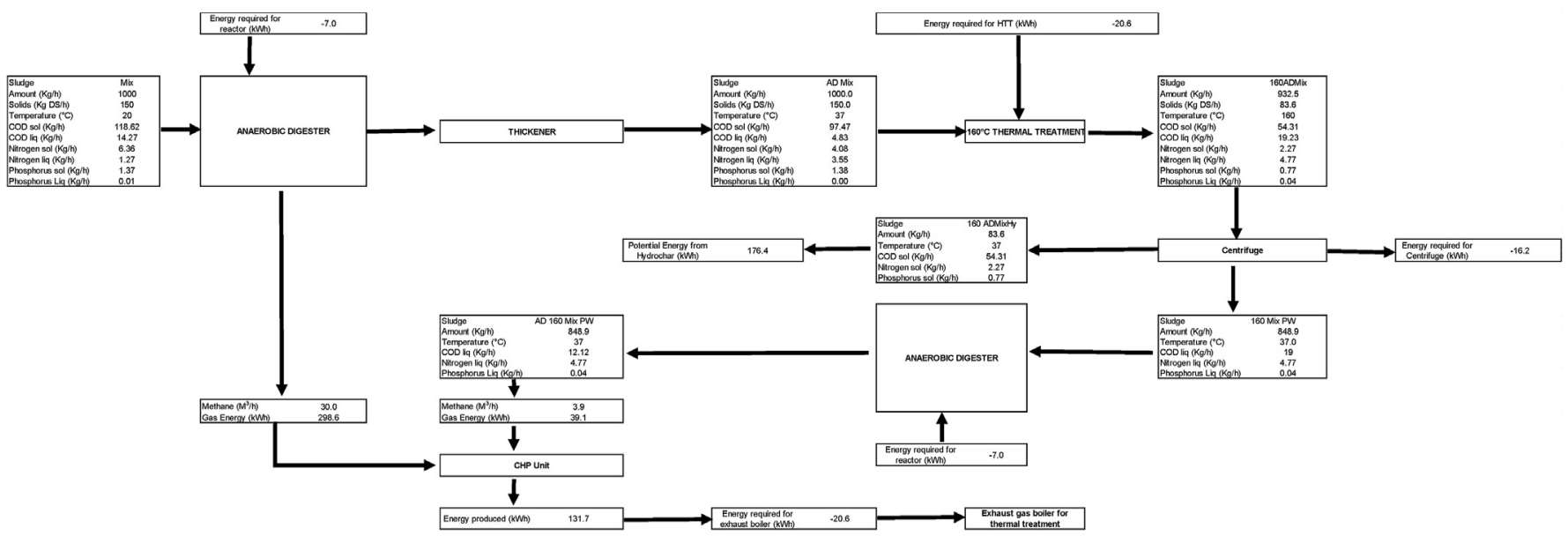

Fig. 2. Mass and energy balance scenarios of the a) Primary Sludge, b) Secondary Sludge and c) Mix Sludge at $160{ }^{\circ} \mathrm{C}$ thermal treatment. 
a) Scenario 4

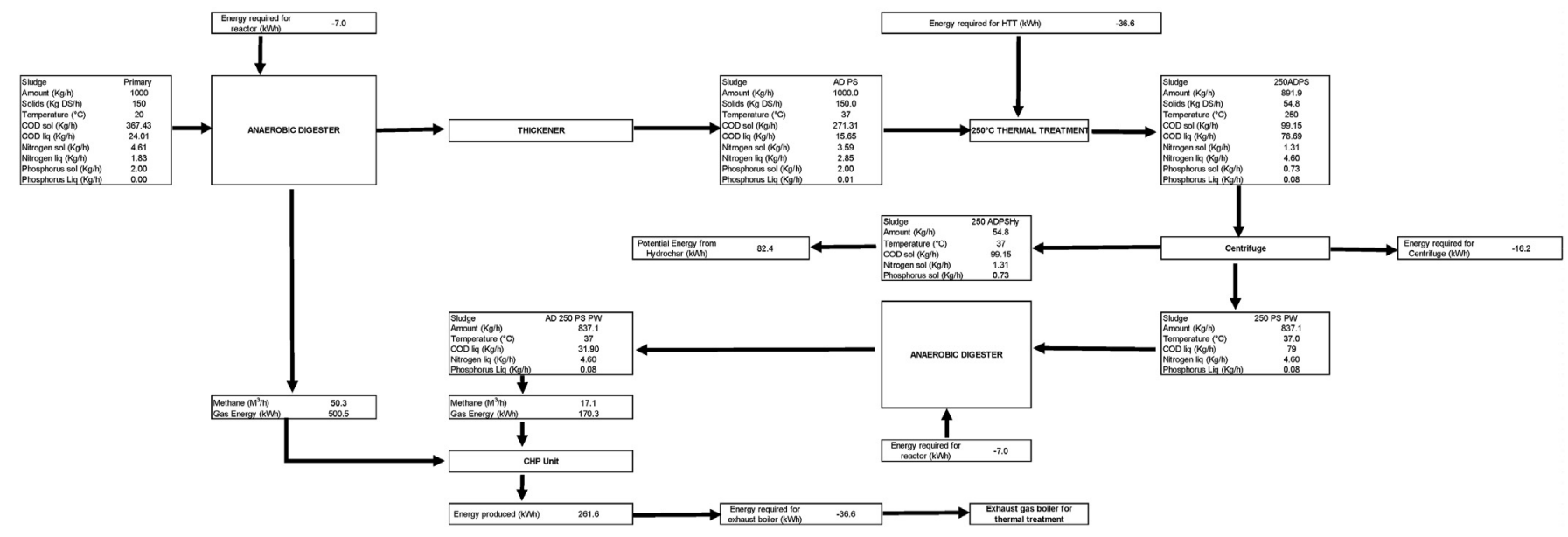

b) Scenario 5

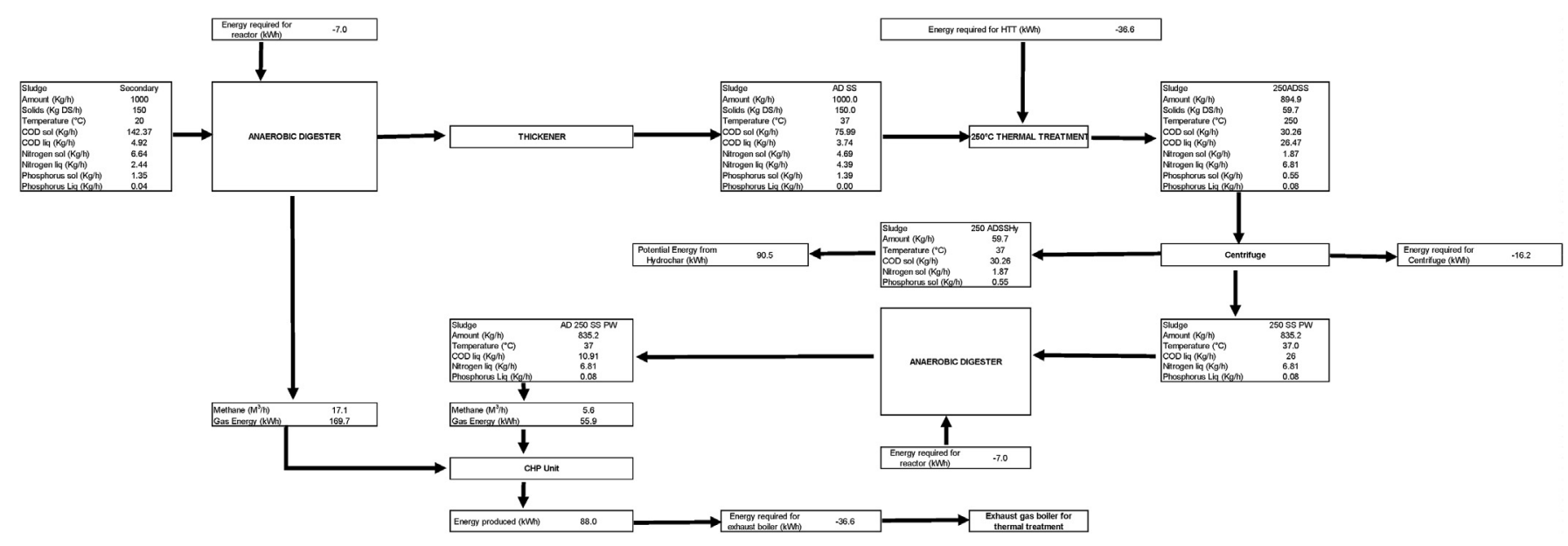

c) Scenario 6

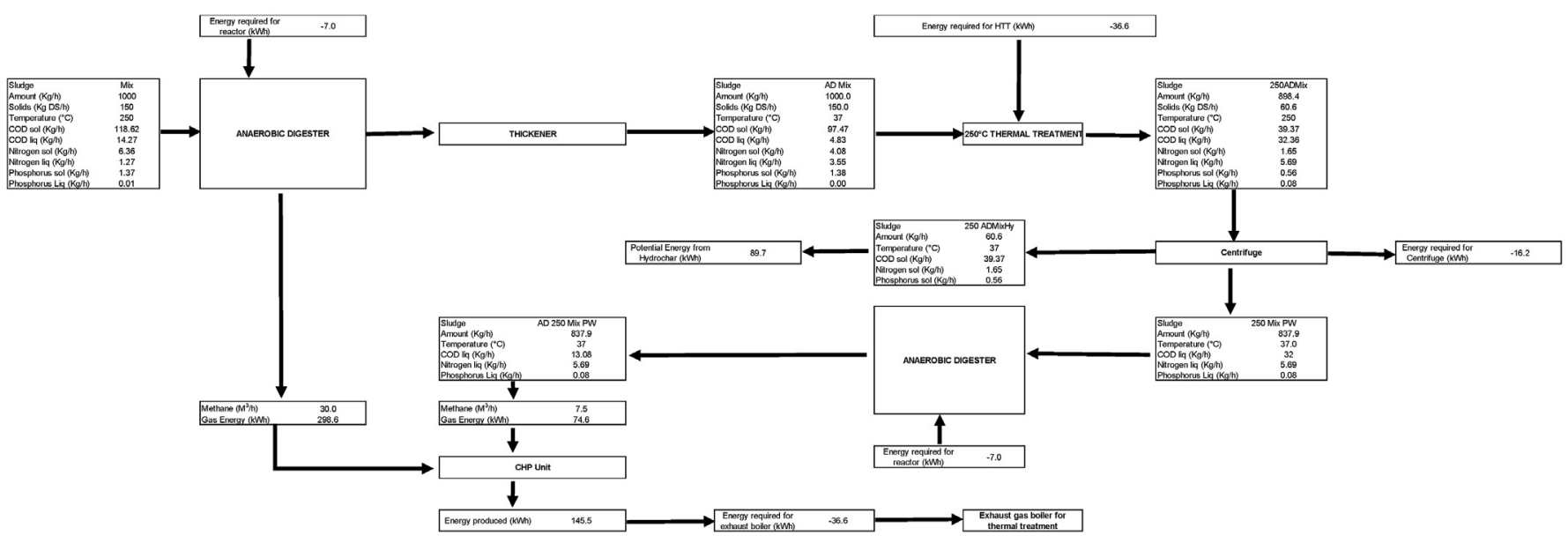

Fig. 3. Mass and energy balance scenarios of the a) Primary Sludge, b) Secondary Sludge and c) Mix Sludge at $250{ }^{\circ} \mathrm{C}$ thermal treatment. 
Table 3

Results from mass balances in each proposed scenario.

\begin{tabular}{|c|c|c|c|c|}
\hline & Total solids reduction, $\%$ & Total COD removal, \% & Total methane production $\left(\mathrm{m}^{3} /\right.$ tonne of sludge) & Total Hydrochar Production (kg/tonne of sludge) \\
\hline Scenario 1 & $56 \%$ & $56 \%$ & 57.0 & 75.6 \\
\hline Scenario 2 & $47 \%$ & $46 \%$ & 20.3 & 82.5 \\
\hline Scenario 3 & $56 \%$ & $58 \%$ & 34.0 & 83.6 \\
\hline Scenario 4 & $68 \%$ & $61 \%$ & 67.5 & 54.8 \\
\hline Scenario 5 & $62 \%$ & $51 \%$ & 22.7 & 59.7 \\
\hline Scenario 6 & $68 \%$ & $66 \%$ & 37.5 & 60.6 \\
\hline
\end{tabular}

solids concentration considered for the scenarios was based on the minimum solid concentration that shows positive energy balance.

Table 3 shows COD and Solids reduction efficiencies (\%) of the proposed scenarios. The percentage of solids removed comes from the sum of solids volatilized during the thermal treatment and solids converted into biogas during the AD treatment. Results showed that higher thermal treatments trends to reduce more solids (See Table 3). During thermal treatment, the solids in sludge samples are hydrolysed leading to the increase on water soluble products due the solubilisation of organic and inorganic compounds into the liquid phase [3,36,57-59]. Scenarios with the $160^{\circ} \mathrm{C}$ hydrothermal treatment integrated showed a solids removal between 47 and 56\% and the scenarios with the $250{ }^{\circ} \mathrm{C}$ hydrothermal treatment integrated reported 62-68\%. Scenarios built with PS and Mix sludge did not show significant differences in terms of solids reduction at the same HTP temperature. However, scenarios with the secondary sludge, regardless the temperature treatment, presented the lowest percentage of solids removal with $47 \%$ and $62 \%$ at $160{ }^{\circ} \mathrm{C}$ and $250{ }^{\circ} \mathrm{C}$ thermal treatment, respectively. This might be due the biomass from the SS comes from a biological treatment (aerobic) that makes the organic compounds less biodegradable for the $1 \mathrm{st}$ AD stage and affecting the overall performance of the scenarios.

The overall COD removal reported comes from the sum of COD volatilized during the thermal treatment and COD converted to biogas during the $\mathrm{AD}$ treatment. During the thermal treatment, most of the COD volatilized is normally converted into $\mathrm{CO}_{2}$ [57]. The COD removal results showed a similar trend as the solids removal where higher temperatures presented higher COD removals. Scenarios built with Mix sludge presented the highest overall COD removal for both thermal treatments with $58 \%$ at $160{ }^{\circ} \mathrm{C}$ and $66 \%$ at $250{ }^{\circ} \mathrm{C}$. This is followed by the scenarios built with PS and SS where the COD removals were 56 and $46 \%$ at $160{ }^{\circ} \mathrm{C}$ and 61 and $51 \%$ at $250{ }^{\circ} \mathrm{C}$, respectively. In addition, if it is considered that after the 2 nd $\mathrm{AD}$ stage the COD concentration corresponded to $4-8 \%$ of the total initial concentration for all the scenarios (See Figs. 2 and 3), that means that most of the COD has the potential to be degraded through energy generation either from biogas or hydrochar combustion. The remaining liquid waste also can be used for irrigation due its high amount of nutrients (see Table 4) or reused into the thermal treatment if more liquid is required for co-processing the sewage sludge with other biomass.

Table 3 also shows methane and hydrochar production of the different scenarios. The methane production did not show a clear correlation with the overall COD and solids removed. Scenarios 1 and 4 that used PS as initial feedstock and thermal treatments temperatures of 160 and $250{ }^{\circ} \mathrm{C}$, showed the highest overall methane production with 57 and $67.5 \mathrm{~m}^{3}$ /tonne of sludge, respectively. This might be due the high organic content in the feedstock that has no receive any previous biological treatment. On the other hand, the SS sample presented the lowest methane production for both thermal treatments at 160 and $250{ }^{\circ} \mathrm{C}$ with 20.3 and $22.7 \mathrm{~m}^{3}$ / tonne of sludge, respectively. This might be due the previous biological treatment received which makes the remaining COD less suitable for methane conversion.
Hydrochars produced during hydrothermal treatments varied in all tested scenarios because they heavily depend on feedstock characteristics and process conditions $[3,18,36]$. Scenarios with $160{ }^{\circ} \mathrm{C}$ treatment temperature $(1-3)$ presented higher hydrochar production than $250{ }^{\circ} \mathrm{C}$ treatment temperature scenarios (4-6). Reaction temperature condition played a key role in the total hydrochar production for the scenarios. This is because as the reaction temperature increases, the hydrochar yield hydrochar decreases [3,12]. Moreover, scenarios that used PS as an initial feedstock ( 1 and 4 ), showed the lowest hydrochar production with 75.6 and $54.8 \mathrm{~kg} /$ tonne of sludge. Scenarios built with Mix and SS, presented similar hydrochar production at the same treatment temperature - i.e., scenarios 2 and 3 (HTT $160{ }^{\circ} \mathrm{C}$ ) showed a hydrochar production of 82.5 and $83.6 \mathrm{~kg} /$ tonne respectively and scenarios 5 and $6\left(\mathrm{HTT} 250{ }^{\circ} \mathrm{C}\right.$ ) a production of 59.7 and $60.6 \mathrm{~kg} /$ tonne of sludge respectively.

Scenarios built with PS (1 and 4) showed the highest biogas and hydrochar production and can be considered as suitable alternatives for WWTWs without a secondary treatment. On the other hand, scenarios 2 and 5 are not convenient due their low overall biogas and hydrochar production and quality. However, considering the potential costs due the necessary modifications to integrate HTC-AD at a current WWTW, scenarios that involve MIX sludge ( 3 and 6 ) are more suitable compared with the rest of the scenarios. This is due less modifications would be needed to adapt the HTC at the WWTWs compared with the rest of the scenarios that would need separated treatments for PS and SS.

One of the most promising process for simultaneous nitrogen and phosphorus recovery in the waste water sector is through formation and precipitation of ammonium magnesium phosphate $\left(\mathrm{NH}_{4} \mathrm{MgPO}_{4} \cdot 6\left(\mathrm{H}_{2} \mathrm{O}\right)\right)$, also known as struvite [60]. Some authors have demonstrated that during hydrothermal treatment there are nitrogen and phosphorus solubilisation from the raw sewage digestate to the liquid fraction [3,36,61]. Figs. 2 and 3 presents nitrogen and phosphorus mass balances and Table 4 the nitrogen and phosphorus available for the potential struvite production per ton of sludge in each tested scenario. Scenarios 2 and 5 presented the highest nitrogen concentration extracted; this is due to the fact that SS samples mainly contain biomass from the aerobic treatment which take up nitrogen and phosphorus from waste water. Most of the nitrogen solubilized during thermal treatment was in ammonium form $\left(\mathrm{NH}_{4}^{+}\right)$, which has the potential to be used for struvite precipitation. Previous studies have proven that during thermal treatment the proteins present in sewage sludge hydrolyse forming ammonium which is released into the process waters [3].

On the other hand, most of the phosphorus remained within the solid fraction. The phosphorus solubilisation is carried on during the thermal process due the organic phosphorus compounds (complex phospholipids, DNA and phosphates monoesters) break down into phosphate [36,61]. Although, the fate of $\mathrm{P}$ is highly feedstock dependent during hydrothermal treatment and is linked to the levels of metals presented in the feedstock $[3,36]$. The phosphorus extraction ranged from 0.03 to $0.07 \mathrm{Kg}$ per tonne of sludge in those scenarios (1-3) with $160{ }^{\circ} \mathrm{C}$ treatment and $0.8 \mathrm{Kg}$ 
Table 4

Nitrogen and Phosphorus available for potential struvite production.

\begin{tabular}{|c|c|c|c|c|c|c|c|c|}
\hline & $\begin{array}{l}{ }^{\text {a Nitrogen }} \text { Sol } \\
(\mathrm{kg})\end{array}$ & $\begin{array}{l}{ }^{\text {aNitrogen }} \text { Liq } \\
(\mathrm{kg})\end{array}$ & $\begin{array}{l}{ }^{\mathrm{a}} \mathrm{Ammonia} \\
(\mathrm{kg})\end{array}$ & $\begin{array}{l}\text { aTotal Phosphorus } \\
\text { (kg) } \\
(\mathrm{kg})\end{array}$ & $\begin{array}{l}{ }^{a} \text { Total Phosphorus } \\
\text { (kg) }\end{array}$ & $\begin{array}{l}{ }^{a} \mathrm{PO}_{4}^{-3} \text { in the liquid } \\
(\mathrm{kg})\end{array}$ & $\begin{array}{l}\text { a, b } M g \text { addition } \\
(\mathrm{kg})\end{array}$ & $\begin{array}{l}\text { aStruvite Production } \\
(\mathrm{kg})\end{array}$ \\
\hline Scenario 1 & 1.8 & 3.8 & 3.1 & 1.0 & 0.03 & 0.02 & $0.00^{c}$ & 0.02 \\
\hline Scenario 2 & 2.6 & 5.8 & 4.6 & 0.8 & 0.07 & 0.04 & 0.01 & 0.04 \\
\hline Scenario 3 & 2.3 & 4.8 & 3.8 & 0.8 & 0.04 & 0.02 & $0.00^{c}$ & 0.02 \\
\hline Scenario 4 & 1.3 & 4.6 & 3.7 & 0.7 & 0.08 & 0.06 & 0.01 & 0.06 \\
\hline Scenario 5 & 1.9 & 6.8 & 4.7 & 0.6 & 0.08 & 0.04 & 0.01 & 0.04 \\
\hline Scenario 6 & 1.6 & 5.7 & 4.7 & 0.6 & 0.08 & 0.05 & 0.01 & 0.05 \\
\hline
\end{tabular}

a Per tonne of sludge.

b $\mathrm{Mg}$ needed to be added.

c Value below the decimal position.

per tonne of sludge in those scenarios (4-6) with $250^{\circ} \mathrm{C}$ treatment. This suggest that $250^{\circ} \mathrm{C}$ treatment favoured the phosphorus fixation within the hydrochar unlike the $160{ }^{\circ} \mathrm{C}$ that favoured the phosphorus solubilisation. The majority of phosphorus extracted was inorganic phosphorus $\left(\mathrm{PO}_{4}^{-3}\right)$ ranging from 50 to $75 \%$. However, the amount of soluble phosphorus determined was very low which might be due to the low initial P content in sludge samples as biological P removal is not part of the processes at Esholt's WWTW, where sludge samples were collected. Despite of that, Table 4 shows the potential struvite production in each scenario. Scenarios 4 and 6 showed the highest potential struvite production with 0.06 and $0.05 \mathrm{~kg}$ per tonne of sludge treated respectively.

\subsection{Energy balance}

The summary of the energy balance from the different scenarios is presented in Table 5. The energy production from methane favoured those scenarios with hydrothermal treatments at the highest reaction temperature. The PS sludge had the highest net energy production in all the scenarios followed by the MIX Sludge and the SS sludge with the lowest. Scenarios 1 and 4 (PS) samples had a potential energy production from methane of 221.1 and $261.6 \mathrm{~kW}$ per tonne of sludge respectively. This was followed by scenarios 3 and 6 (MIX) and scenarios 1 and 5 (SS) with a potential energy production from methane of 131.7, 145.5, 78.8 and $88 \mathrm{~kW}$ per tonne of sludge respectively.

On the other hand, the net energy balance favoured the scenarios with HTC processes with the lowest reaction temperature when energy was produced only from biogas. All the scenarios presented a positive energy balance; scenarios 1 and 4 showed the highest net energy balance producing extra 163.3 and $187.8 \mathrm{~kW}$ per tonne of sludge treated, followed by scenarios 3, 6, 2 and 5 with $73.9,71.8,21$ and $14.2 \mathrm{~kW}$ extra tonne of sludge respectively. This potential extra energy produced can be used either for the total WWTW energy needs or for electricity exportation.

When only biogas production is considered as the only energy source in the proposed systems, the net energy production reduces significantly in comparison when the hydrochar is included as an energetic. For that reason it is important the hydrochar inclusion as a fuel source within the system in order to make a more selfsustainable. Despite of the quality of hydrochar samples, the net energy production in each scenario is enhanced with the inclusion of the energy that comes from hydrochars if used as a low-grade fuel. According to Aragón-Briceño, Ross and Camargo-Valero [3], between 56 and 59\% of the energy produced in an AD + HTC process comes from the hydrochar. Scenarios with lower treatment temperature (1,2 and 3) have more potential for energy production from hydrochar. The hydrochar yield is higher at lower treatment temperatures compared with those scenarios with a higher treatment temperature $(4,5$ and 6$)$. The hydrochar fraction represents between 40 and $68 \%$ for scenarios with $160{ }^{\circ} \mathrm{C}$ treatment and between 24 and $51 \%$ for the scenarios with $250{ }^{\circ} \mathrm{C}$ treatment of the overall potential energy production. Therefore, the inclusion of the hydrochar as an energy source is directly reflected on the net energy balance which would be enhanced between 89 and $642 \%$ for scenarios with $160{ }^{\circ} \mathrm{C}$ treatment and between 42 and $435 \%$ for the scenarios with $250{ }^{\circ} \mathrm{C}$ treatment. Other studies have reported that the implementation of the thermal treatment at the end of the process favours the overall energy production up to $179 \%$ in comparison with the traditional AD [3]. Wang, Chang and Li [37] reported a positive overall energy recovery from the HTC of sewage sludge coupled with AD (668 MJ per tonne treated), where hydrochar contributed to $59 \%$ of the potential energy recovered. Medina-Martos, Istrate, Villamil, Gálvez-Martos, Dufour and Mohedano [9] reported in their study a contribution of $77 \%$ (562 MJ) from hydrochar to the total potential energy production of a HTC + AD system.

\subsection{Economics}

In the United Kingdom the tariff rates for electricity exportation from renewable sources is established by the Office of Gas and Electricity Markets [62]. This is a non-ministerial government department and an independent National Regulatory Authority recognised by EU Directives and governed by the Gas and Electricity Markets Authority (GEMA). The tariff rates for anaerobic digestion

Table 5

Results from energy balance per tonne of sludge processed in each scenario.

\begin{tabular}{|c|c|c|c|c|c|}
\hline & $\begin{array}{l}{ }^{\mathrm{a}} \text { Energy consumed } \\
(\mathrm{kWh})\end{array}$ & $\begin{array}{l}{ }^{a} \text { Energy produced from } \\
\text { Methane }(\mathrm{kWh})\end{array}$ & $\begin{array}{l}{ }^{\mathrm{a}} \text { Net Energy } \\
\text { balance (kWh) }\end{array}$ & $\begin{array}{l}\text { aPotential Energy from the } \\
\text { hydrochar (kWh) }\end{array}$ & $\begin{array}{l}\text { aNet Energy balance including } \\
\text { hydrochar }(\mathrm{kWh})\end{array}$ \\
\hline Scenario 1 & 57.8 & 221.1 & 163.3 & 149.6 & 312.9 \\
\hline Scenario 2 & 57.8 & 78.8 & 21.0 & 169.6 & 190.5 \\
\hline Scenario 3 & 57.8 & 131.7 & 73.9 & 176.4 & 250.2 \\
\hline Scenario 4 & 73.8 & 261.6 & 187.8 & 82.4 & 270.2 \\
\hline Scenario 5 & 73.8 & 88.0 & 14.2 & 90.5 & 104.7 \\
\hline Scenario 6 & 73.8 & 145.5 & 71.8 & 89.7 & 161.4 \\
\hline
\end{tabular}

\footnotetext{
${ }^{a}$ Per tonne of sludge.
} 
Table 6

Potential economic benefits of integrating HTC with AD.

\begin{tabular}{|c|c|c|c|c|c|}
\hline & $\begin{array}{l}\text { Electricity production profit from } \\
\text { methane per tonne of sewage } \\
\text { sludge }(€)\end{array}$ & $\begin{array}{l}\text { Electricity production profit from } \\
\text { Hydrochar per tonne of sewage sludge } \\
(€)\end{array}$ & $\begin{array}{l}\text { aStruvite production profit per } \\
\text { tonne of sewage sludge }(€)\end{array}$ & $\begin{array}{l}\text { Total profit per } \\
\text { tonne sludge }(€)\end{array}$ & $\begin{array}{l}\text { Total profit for WWTW } \\
\text { serving a } 100,000 \text { p.e. }(€)\end{array}$ \\
\hline Scenario 1 & 9.02 & 7.92 & 9.21 & 26.15 & 392,306 \\
\hline Scenario 2 & 1.48 & 8.98 & 18.08 & 28.54 & 428,094 \\
\hline Scenario 3 & 4.28 & 9.34 & 9.10 & 22.72 & 340,798 \\
\hline Scenario 4 & 10.32 & 4.36 & 26.24 & 40.92 & 613,869 \\
\hline Scenario 5 & 1.12 & 4.79 & 20.19 & 26.10 & 391,518 \\
\hline Scenario 6 & 4.17 & 4.75 & 23.52 & 32.44 & 486,528 \\
\hline
\end{tabular}

Exchange rate $£ 1=€ 1.1197$ [66].

depends on the plant capacity for electricity generation. In this study, the lowest tariff of $5.30 \mathrm{p} / \mathrm{kWh}$ (Euro) was considered as the based tariff for the electricity produced from methane [62]. The same tariff was considered for potential electricity production from the hydrochar since there are not clear information about it.

In Table 6, the summary of economic benefits of integrating HTC with $\mathrm{AD}$ are shown. The potential profit from methane production ranged from $€ 1.12$ to $€ 10.32$ per tonne of sewage sludge treated. The economic analysis for the scenarios using PS ( 1 and 4 ) had the highest potential economic benefits with $€ 9.02$ per tonne of sludge at $160{ }^{\circ} \mathrm{C}$ and $€ 10.32$ per tonne of sludge at $250{ }^{\circ} \mathrm{C}$ showing an increase when as the reaction temperature increases. Scenarios with MIX sludge (3 and 6) presented an economic benefit of $€ 4.28$ and $€ 4.17$ per tonne of sludge, respectively and SS scenarios ( 2 and 4) showed the lowest economic benefit with $€ 1.12$ and $€ 1.28$ per tonne of sludge respectively.

The potential economic benefit from the hydrochar production is slightly higher compared with the biogas production. Some studies have found that the hydrochar production can represents up to $55 \%$ of the total revenue [9]. Hydrochar yield played a key role on the economic benefit showing higher benefits for those scenarios with $160{ }^{\circ} \mathrm{C}$ thermal treatment. For scenarios with $250{ }^{\circ} \mathrm{C}$ thermal treatment, the economic benefits had not significative difference regardless the type of sewage used as feedstock. The benefit ranged from $€ 4.36-€ 4.79$ per tonne of sludge treated. These benefits from hydrochar production might be increased if coprocessing sewage sludge with other biomass feedstocks is considered in order to increase the quality properties of the hydrochar [63].

For this study, the price for the struvite was considered based on that average price for the struvite in the fertiliser market is $€ 475.5$ per tonne [60]. The economic benefit per tonne of sludge ranged from $€ 9.10$ to $€ 18.08$ for scenarios with $160{ }^{\circ} \mathrm{C}$ thermal treatment and between $€ 20.19$ to $€ 26.24$ for scenarios when the $250{ }^{\circ} \mathrm{C}$ thermal treatment was considered. Nonetheless, despite of the cost of phosphorus recovering as struvite can range from $€ 2$ up to $€ 8$ per $\mathrm{kg}$ of $\mathrm{P}$ recovered, the struvite production from the process waters still showed to be a good opportunity area for increase the overall profit, especially if other feedstocks with high phosphorus content are co-processed with the sewage sludge [60,64].

In 2010, the average sewage sludge generation per person in the UK was $22.5 \mathrm{~kg}$ of dry sewage sludge annually [1,65]. Considering a large size WWTW could serve a population of about 100,000 p. e. i.e., an annual production of 15,000 tonnes of sewage sludge (15\% of dry solids) - the economic benefits per year depending on the tested scenario would range from $€ 16,832$ to $€ 1514,788$ from biogas production; $€ 65,429$ to $€ 140,102$ from hydrochar production and $€ 136,449$ to $€ 393,652$ from struvite production (without considering the price of $\mathrm{Mg}$ addition and $\mathrm{pH}$ regulation process). The scenarios where the $250{ }^{\circ} \mathrm{C}$ treatment was applied showed the best potential for increasing profits with $€ 613,869$ and $€ 486,528$ for scenarios 4 and 6 respectively (See Table 6).
Therefore, taking into account all the variables involved in this analysis (waste reduction, energy production and economic benefits), scenarios 4 and 6 showed to be the more suitable for the integration of HTC with AD in a WWTW. However, more variables and many other aspects have to be considered for a more complete analysis as the cost of the WWTW's modifications needed, cost of a struvite production process plant, cost of an energy generator from solid biomass fuel, etc.

\section{Conclusions}

A complete HTC + AD system for integration in a WWTW was proposed. Six different scenarios were evaluated built with 3 different sewage sludge (PS, SS and MIX) and 2 different thermal treatments $\left(160\right.$ and $\left.250{ }^{\circ} \mathrm{C}\right)$. It was found that the integration of HTC-AD, through the proposed scenarios, presented environmental benefits (waste reduction) such as an overall total solid and COD reduction up to 68 and $66 \%$ respectively. In addition, the integration of the HTC-AD process showed a positive energy balance in all the proposed scenarios with a maximum net energy production of $312.9 \mathrm{~kW} \mathrm{~h}$ per tonne of treated sludge if the hydrochar is considered as a fuel source.

The economic analysis for the proposed scenarios showed a potential benefit up to $€ 613,869$ as long as the struvite production is considered as a part of the whole system. Scenarios that included PS and MIX sludge with $250{ }^{\circ} \mathrm{C}$ thermal treatment showed to be the more suitable options for HTC + AD integration if organic matter removal, energy harnessing and economic feasibility are considered as main variables. Nonetheless, still many aspects have to be considered regarding capital costs for retrofitting existing WWTWs and the addition of complementary equipment for the use of hydrochar as an energy source. In addition, HTC co-processing of other feedstocks with $\mathrm{AD}$ sludge needs to be considered as a complementary option as it might enhance the quality of $\mathrm{AD}$ products (process waters and hydrochar) and therefore the overall economic and environmental benefits.

\section{Declaration of competing interest}

The authors declare that they have no known competing financial interests or personal relationships that could have appeared to influence the work reported in this paper.

\section{Acknowledgments}

The authors would like to thank the Consejo Nacional de Ciencia y Tecnología of Mexico (CONACYT) for the financial support provided to Dr Christian Aragón-Briceño as part of his PhD Scholarship (248333/383197) at the University of Leeds. 


\section{References}

[1] DEFRA, Waste water treatment in the united kingdonm - 2012, 2015, https:// www.gov.uk/government/uploads/system/uploads/attachment_data/file/ 69592/pb13811-waste-water-2012.pdf, 2012. (Accessed 3 August 2015).

[2] N. Mills, P. Pearce, J. Farrow, R.B. Thorpe, N.F. Kirkby, Environmental \& economic life cycle assessment of current \& future sewage sludge to energy technologies, Waste Manag. 34 (1) (2014) 185-195.

[3] C. Aragón-Briceño, A.B. Ross, M.A. Camargo-Valero, Evaluation and comparison of product yields and bio-methane potential in sewage digestate following hydrothermal treatment, Appl. Energy 208 (Supplement C) (2017) 1357-1369.

[4] D. Kim, K. Lee, K.Y. Park, Hydrothermal carbonization of anaerobically digested sludge for solid fuel production and energy recovery, Fuel 130 (2014) $120-125$.

[5] M. Berglund, P. Börjesson, Assessment of energy performance in the life-cycle of biogas production, Biomass Bioenergy 30 (3) (2006) 254-266.

[6] S. Pilli, S. Yan, R.D. Tyagi, R.Y. Surampalli, Thermal pretreatment of sewage sludge to enhance anaerobic digestion: a review, Crit. Rev. Environ. Sci. Technol. 45 (6) (2015) 669-702.

[7] M. Hindle, Anaerobic digestion IN the United Kingdom, Biocycle 54 (5) (2013) $41-43$.

[8] J.M. Abelleira-Pereira, S.I. Pérez-Elvira, J. Sánchez-Oneto, R. de la Cruz, J.R. Portela, E. Nebot, Enhancement of methane production in mesophilic anaerobic digestion of secondary sewage sludge by advanced thermal hydrolysis pretreatment, Water Res. 71 (2015) 330-340, 0.

[9] E. Medina-Martos, I.-R. Istrate, J.A. Villamil, J.-L. Gálvez-Martos, J. Dufour, Á.F. Mohedano, Techno-economic and life cycle assessment of an integrated hydrothermal carbonization system for sewage sludge, J. Clean. Prod. 277 (2020) 122930.

[10] C. He, A. Giannis, J.-Y. Wang, Conversion of sewage sludge to clean solid fuel using hydrothermal carbonization: hydrochar fuel characteristics and combustion behavior, Appl. Energy 111 (2013) 257-266.

[11] P. Zhao, Y. Shen, S. Ge, K. Yoshikawa, Energy recycling from sewage sludge by producing solid biofuel with hydrothermal carbonization, Energy Convers. Manag. 78 (2014) 815-821.

[12] C.I. Aragón-Briceño, O. Grasham, A.B. Ross, V. Dupont, M.A. Camargo-Valero, Hydrothermal carbonization of sewage digestate at wastewater treatment works: influence of solid loading on characteristics of hydrochar, process water and plant energetics, Renew. Energy 157 (2020) 959-973.

[13] J.A. Villamil, A.F. Mohedano, J.J. Rodriguez, M.A.d.l. Rubia, Valorisation of the liquid fraction from hydrothermal carbonisation of sewage sludge by anaerobic digestion, J. Chem. Technol. Biotechnol. 93 (2) (2018) 450-456.

[14] M.A. De la Rubia, J.A. Villamil, J.J. Rodriguez, A.F. Mohedano, Effect of inoculum source and initial concentration on the anaerobic digestion of the liquid fraction from hydrothermal carbonisation of sewage sludge, Renew. Energy 127 (2018) 697-704.

[15] M.T. Au - Reza, M. Au - Werner, M. Au - Pohl, J. Au - Mumme, Evaluation of integrated anaerobic digestion and hydrothermal carbonization for bioenergy production, JoVE (88) (2014), e51734.

[16] N.D. Berge, K.S. Ro, J. Mao, J.R.V. Flora, M.A. Chappell, S. Bae, Hydrothermal carbonization of municipal waste streams, Environ. Sci. Technol. 45 (13) (2011) 5696-5703.

[17] R.Z. Gaur, O. Khoury, M. Zohar, E. Poverenov, R. Darzi, Y. Laor, R. Posmanik, Hydrothermal carbonization of sewage sludge coupled with anaerobic digestion: integrated approach for sludge management and energy recycling, Energy Convers. Manag. 224 (2020) 113353.

[18] E. Danso-Boateng, G. Shama, A.D. Wheatley, S.J. Martin, R.G. Holdich, Hydrothermal carbonisation of sewage sludge: effect of process conditions on product characteristics and methane production, Bioresour. Technol. 177 (2015) 318-327, 0.

[19] M. Lucian, L. Fiori, Hydrothermal carbonization of waste biomass: process design, modeling, energy efficiency and cost analysis, Energies 10 (211) (2017) 18.

[20] B. Wirth, T. Reza, J. Mumme, Influence of digestion temperature and organic loading rate on the continuous anaerobic treatment of process liquor from hydrothermal carbonization of sewage sludge, Bioresour. Technol. 198 (2015) 215-222.

[21] P. Biller, A.B. Ross, Hydrothermal processing of algal biomass for the production of biofuels and chemicals, Biofuels 3 (5) (2012) 603-623.

[22] N. Gao, Z. Li, C. Quan, N. Miskolczi, A. Egedy, A new method combining hydrothermal carbonization and mechanical compression in-situ for sewage sludge dewatering: bench-scale verification, J. Anal. Appl. Pyrol. 139 (2019) $187-195$.

[23] J.A. Villamil, A.F. Mohedano, J. San Martín, J.J. Rodriguez, M.A. de la Rubia, Anaerobic co-digestion of the process water from waste activated sludge hydrothermally treated with primary sewage sludge. A new approach for sewage sludge management, Renew. Energy 146 (2020) 435-443.

[24] J.A. Villamil, A.F. Mohedano, J.J. Rodríguez, R. Borja, M.A. De la Rubia, Anaerobic Co-digestion of the organic fraction of municipal solid waste and the liquid fraction from the hydrothermal carbonization of industrial sewage sludge under, Thermophilic Conditions 2 (17) (2018).

[25] J.A. Villamil, A.F. Mohedano, J.J. Rodriguez, M.A. De la Rubia, Anaerobic codigestion of the aqueous phase from hydrothermally treated waste activated sludge with primary sewage sludge. A kinetic study, J. Environ. Manag. 231 (2019) 726-733.

[26] J.A. Villamil, A.F. Mohedano, J.J. Rodriguez, M.A. de la Rubia, Valorisation of the Liquid Fraction from Hydrothermal Carbonisation of Sewage Sludge by Anaerobic Digestion, vol. 93, 2018, pp. 450-456, 2.

[27] E. Nyktari, A. Wheatley, E. Danso-Boateng, R. Holdich, Anaerobic Digestion of Liquid Products Following Hydrothermal Carbonisation of Sewage Sludge with Different Reaction Conditions, 13th IWA Specialized Conference on Small Water and Wastewater Systems \& 5th IWA Specialized Conference on Resources-Oriented Sanitation, Desalination Publications, Athens, Greece, 2017, pp. 1-7.

[28] R. Becker, U. Dorgerloh, E. Paulke, J. Mumme, I. Nehls, Hydrothermal carbonization of biomass: major organic components of the aqueous phase, Chem. Eng. Technol. 37 (3) (2014) 511-518.

[29] W. Wang, H. Hou, S. Hu, X. Gao, Performance and stability improvements in anaerobic digestion of thermally hydrolyzed municipal biowaste by a biofilm system, Bioresour. Technol. 101 (6) (2010) 1715-1721.

[30] H. Ahn, D. Kim, Y. Lee, Combustion characteristics of sewage sludge solid fuels produced by drying and hydrothermal carbonization in a fluidized bed Renew. Energy 147 (2020) 957-968.

[31] L. Li, J.R.V. Flora, N.D. Berge, Predictions of energy recovery from hydrochar generated from the hydrothermal carbonization of organic wastes, Renew. Energy 145 (2020) 1883-1889.

[32] J. Pagés-Díaz, A.O. Cerda Alvarado, S. Montalvo, L. Diaz-Robles, C.H. Curio, Anaerobic bio-methane potential of the liquors from hydrothermal carbonization of different lignocellulose biomasses, Renew. Energy 157 (2020) $182-189$.

[33] K.R. Parmar, A.B. Ross, Integration of hydrothermal carbonisation with anaerobic digestion, Opportunities for Valorisation of Digestate, Energies 12 (9) (2019) 1586.

[34] M. Wilk, A. Magdziarz, K. Jayaraman, M. Szymańska-Chargot, I. Gökalp, Hydrothermal carbonization characteristics of sewage sludge and lignocellulosic biomass, A comparative study, Biomass and Bioenergy 120 (2019) 166-175.

[35] T. Koottatep, K. Fakkaew, N. Tajai, S.V. Pradeep, C. Polprasert, Sludge stabilization and energy recovery by hydrothermal carbonization process, Renew. Energy 99 (2016) 978-985.

[36] U. Ekpo, A.B. Ross, M. Camargo-Valero, A comparison of product yields and inorganic content in process setreams following thermal hydrolysis and hydrothermal processing of microalgae, manure and digestate, Bioresour. Technol. 200 (2015) 951-960.

[37] L. Wang, Y. Chang, A. Li, Hydrothermal carbonization for energy-efficient processing of sewage sludge: a review, Renew. Sustain. Energy Rev. 108 (2019) 423-440.

[38] M. Hitzl, A. Corma, F. Pomares, M. Renz, The hydrothermal carbonization (HTC) plant as a decentral biorefinery for wet biomass, Catal. Today 257 (2015) 154-159.

[39] J. Stemann, F. Ziegler, Assessment of the Energetic Efficiency of A Continuously Operating Plant for Hydrothermal Carbonisation of Biomass, 2011.

[40] Ingelia (2019). https://ingelia.com/?lang=en. (Accessed 16 October 2019).

[41] SunCoal Industries. https://www.suncoal.com/company/, 2019. (Accessed 18 October 2019).

[42] () TerraNova Energy GmbH. http://terranova-energy.com/en/, 2019. (Accessed 20 October 2019).

[43] AVA-CO2. http://ava-htc.com/, 2019. (Accessed 16 October 2019).

[44] CarboRem, 2020, http://www.carborem.com/english/, 2020. (Accessed 12 November 2020).

[45] M. Child, Industrial-scale Hydrothermal Carbonization of Waste Sludge Materials for Fuel Production, Faculty of Technology, LAPPEENRANTA UNIVERSITY OF TECHNOLOGY, Finland, 2014, p. 109.

[46] Z. Cao, B. Hülsemann, D. Wüst, L. Illi, H. Oechsner, A. Kruse, Valorization of maize silage digestate from two-stage anaerobic digestion by hydrothermal carbonization, Energy Convers. Manag. 222 (2020) 113218.

[47] M. Lucian, M. Volpe, F. Merzari, D. Wüst, A. Kruse, G. Andreottola, L. Fiori, Hydrothermal carbonization coupled with anaerobic digestion for the valorization of the organic fraction of municipal solid waste, Bioresour. Technol. 314 (2020) 123734.

[48] F. Merzari, M. Langone, G. Andreottola, L. Fiori, Methane production from process water of sewage sludge hydrothermal carbonization. A review. Valorising sludge through hydrothermal carbonization, Crit. Rev. Environ. Sci. Technol. 49 (11) (2019) 947-988.

[49] J. Mumme, M.-M. Titirici, A. Pfeiffer, U. Lüder, M.T. Reza, O. Mašek, Hydrothermal carbonization of digestate in the presence of zeolite: process efficiency and composite properties, ACS Sustain. Chem. Eng. 3 (11) (2015) $2967-2974$.

[50] S.I. Pérez-Elvira, F. Fdz-Polanco, Continuous thermal hydrolysis and anaerobic digestion of sludge, Energy integration study, Water Science and Technology 65 (10) (2012) 1839-1846.

[51] S.A. Channiwala, P.P. Parikh, A unified correlation for estimating HHV of solid, liquid and gaseous fuels, Fuel 81 (8) (2002) 1051-1063.

[53] M.B. Shemfe, S. Gu, P. Ranganathan, Techno-economic performance analysis of biofuel production and miniature electric power generation from biomass fast pyrolysis and bio-oil upgrading, Fuel 143 (2015) 361-372.

[54] Sridhar Pilli, Yan Song, R.D. Tyagi, R.Y. Surampalli, Thermal pretreatment of sewage sludge to enhance anaerobic digestion: a review, Crit. Rev. Environ. Sci. Technol. 45 (6) (2015) 669-702. 
[55] K. Smith, S. Liu, Energy for conventional water supply and wastewater treatment in urban China: a review, Global Challenges 1 (5) (2017). 1600016n/a.

[56] G. Oreggioni, B. Gowreesunker, S. Tassou, G. Bianchi, M. Reilly, M. Kirby, T. Toop, M. Theodorou, Potential for Energy Production from Farm Wastes Using Anaerobic Digestion in the UK: an Economic Comparison of Different Size Plants, 2017.

[57] I. Zabaleta, P. Marchetti, C.R. Lohri, C. Zurbrügg, Influence of solid content and maximum temperature on the performance of a hydrothermal carbonization reactor, Environ. Technol. (2017) 1-10.

[58] P. Keymer, I. Ruffell, S. Pratt, P. Lant, High pressure thermal hydrolysis as pretreatment to increase the methane yield during anaerobic digestion of microalgae, Bioresour. Technol. 131 (2013) 128-133, 0.

[59] W. Qiao, X. Yan, J. Ye, Y. Sun, W. Wang, Z. Zhang, Evaluation of biogas production from different biomass wastes with/without hydrothermal pretreatment, Renew. Energy 36 (12) (2011) 3313-3318.

[60] M. Molinos-Senante, F. Hernández-Sancho, R. Sala-Garrido, M. Garrido-Baserba, Economic feasibility study for phosphorus recovery processes, Ambio 40 (4) (2011) 408-416.

[61] L. Dai, F. Tan, B. Wu, M. He, W. Wang, X. Tang, Q. Hu, M. Zhang, Immobilization of phosphorus in cow manure during hydrothermal carbonization, J. Environ. Manag. 157 (2015) 49-53.

[62] Ofgem, Feed-in tariff (FIT) rates, 2018, https://www.ofgem.gov.uk/ environmental-programmes/fit/fit-tariff-rates, 2018. (Accessed 19 July 2018).

[63] Y. Zhai, C. Peng, B. Xu, T. Wang, C. Li, G. Zeng, Y. Zhu, Hydrothermal carbonisation of sewage sludge for char production with different waste biomass: effects of reaction temperature and energy recycling, Energy 127 (2017) 167-174.

[64] B.K. Mayer, L.A. Baker, T.H. Boyer, P. Drechsel, M. Gifford, M.A. Hanjra, P. Parameswaran, J. Stoltzfus, P. Westerhoff, B.E. Rittmann, Total value of phosphorus recovery, Environ. Sci. Technol. 50 (13) (2016) 6606-6620.

[65] Office for National Statistics, Revised Annual Mid-year Population Estimates, UK: 2001 to 2010, 2013, 2018, https://www.ons.gov.uk/ peoplepopulationandcommunity/populationandmigration/ populationestimates/bulletins/annualmidyearpopulationestimates/2013-12 17. (Accessed 19 July 2018).

[66] Bank of England, Daily spot exchange rates against Sterling, 2018, https:// www.bankofengland.co.uk/boeapps/database/Rates.asp? Travel=NIxAZx\&amp;into=GBP, 2018. (Accessed 19 July 2018). 